Article

\title{
Low-Noble-Metal-Loading Hybrid Catalytic System for Oxygen Reduction Utilizing Reduced-Graphene-Oxide-Supported Platinum Aligned with Carbon-Nanotube-Supported Iridium
}

\author{
Beata Dembinska ${ }^{1, *} \oplus$, Agnieszka Zlotorowicz ${ }^{1}$, Magdalena Modzelewska ${ }^{1}$, \\ Krzysztof Miecznikowski ${ }^{1}{ }^{(0)}$, Iwona A. Rutkowska ${ }^{1} \mathbb{D}$, Leszek Stobinski ${ }^{2}$, Artur Malolepszy ${ }^{2}{ }^{(\mathbb{D}}$, \\ Maciej Krzywiecki ${ }^{3}$, Jerzy Zak ${ }^{1}$, Enrico Negro ${ }^{4}$ (D), Vito Di Noto ${ }^{4}$ and Pawel J. Kulesza ${ }^{1, *(D)}$ \\ 1 Faculty of Chemistry, University of Warsaw, Pasteura 1, PL-02-093 Warsaw, Poland; \\ azlotorowicz@chem.uw.edu.pl (A.Z.); magdalena.modzelewska@student.uw.edu.pl (M.M.); \\ kmiecz@chem.uw.edu.pl (K.M.); ilinek@chem.uw.edu.pl (I.A.R.); Jerzy.zak@vp.pl (J.Z.) \\ 2 Faculty of Chemical and Process Engineering, Warsaw University of Technology, Warynskiego 1, \\ PL-00-645 Warsaw, Poland; leszek.stobinski@pw.edu.pl (L.S.); artur.malolepszy@pw.edu.pl (A.M.) \\ 3 Institute of Physics-CSE, Silesian University of Technology, Konarskiego 22B, PL-44-100 Gliwice, Poland; \\ maciej.krzywiecki@polsl.pl \\ 4 Department of Industrial Engineering, Università degli Studi di Padova in Department of Chemical Sciences, \\ Via Marzolo 1, 35131 Padova (PD), Italy; enrico.negro@unipd.it (E.N.); vito.dinoto@unipd.it (V.D.N.) \\ * Correspondence: bbaranowska@chem.uw.edu.pl (B.D.); pkulesza@chem.uw.edu.pl (P.J.K.); \\ Tel.: +48-2255-26-336 (B.D.); +48-2255-26-344 (P.J.K.)
}

Received: 17 May 2020; Accepted: 16 June 2020; Published: 19 June 2020

\begin{abstract}
Hybrid systems composed of the reduced graphene oxide-supported platinum and multiwalled carbon nanotube-supported iridium (both noble metals utilized at low loadings on the level of 15 and $\leq 2 \mu \mathrm{g} \mathrm{cm}^{-2}$, respectively) were considered as catalytic materials for the reduction of oxygen in acid media ( $\left.0.5-\mathrm{mol} \mathrm{dm}^{-3} \mathrm{H}_{2} \mathrm{SO}_{4}\right)$. The electrocatalytic activity toward reduction of oxygen and formation of hydrogen peroxide intermediate are tested using rotating ring-disk electrode (RRDE) voltammetric experiments. The efficiency of the proposed catalytic systems was also addressed by performing galvanodynamic measurements with gas diffusion electrode (GDE) half-cell at $80^{\circ} \mathrm{C}$. The role of carbon nanotubes is to improve charge distribution at the electrocatalytic interface and facilitate the transport of oxygen and electrolyte in the catalytic systems by lowering the extent of reduced graphene oxide restacking during solvent evaporation. The diagnostic electrochemical experiments revealed that-in iridium-containing systems-not only higher disk currents, but also somehow smaller ring currents are produced (when compared to the Ir-free reduced graphene oxide-supported platinum), clearly implying formation of lower amounts of the undesirable hydrogen peroxide intermediate. The enhancement effect originating from the addition of traces of iridium (supported onto carbon nanotubes) to platinum, utilized at low loading, may originate from high ability of iridium to induce decomposition of the undesirable hydrogen peroxide intermediate.
\end{abstract}

Keywords: reduced graphene oxide; carbon nanotubes; platinum catalyst; iridium additive; oxygen reduction reaction; hydrogen peroxide intermediate

\section{Introduction}

Despite appreciable progress in the development of proton exchange membrane fuel cells, their commercialization still requires the lowering of the costs and more durable materials. The problem of electrochemical stability is very important for the operation of cathode under oxidative conditions which 
include low $\mathrm{pH}$, high potentials (especially during startup/shut-down procedures) and the generation of reactive oxygen species from hydrogen peroxide (the intermediate product of oxygen reduction) [1]. The latter issue may become even more serious when lower amounts of expensive Pt catalyst are utilized [2,3] which on one hand, enables to reduce the costs of devices, but on the other hand results in production of higher quantity of undesirable hydrogen peroxide (due to dilution of active centers). Further, high potential of the cathode may cause both the oxidative degradation of carbon support and the dissolution or sintering of platinum nanoparticles. Additionally, it is well recognized that platinum accelerates the corrosion rate of the carbon, what is particularly evident in a case of commonly used carbon blacks [4]. Therefore, there is a need for searching alternative, more corrosion-resistant carriers. In this regard, highly graphitized carbon materials, such as multiwalled carbon nanotubes (MWCNT) or more recently explored graphene-based materials, are considered as promising alternatives for carbon blacks [5,6]. From the family of graphene-related materials, the most perspective and the most widely used (due to facility of manufacturing and relatively low costs) is reduced graphene oxide (rGO). The presence of surface oxygen-containing groups onto corrugated graphene layers facilitates their exfoliation and excellent dispersion of metal nanoparticles with narrow range of sizes what should allow for high utilization of the catalyst. But at the same time, a large population of oxygen functionalities decreases the electronic conductivity of the support which, together with its restacking during slow evaporation of solvents, causes charge and mass (oxygen and water) transport limitations in the catalytic layer [7]. Regarding the catalytic layer intended for oxygen electroreduction, where the reaction proceeds at three-phase boundary and under harsh conditions, the compromise in many planes should be assured. It has been proven for instance that for rGO-supported $\mathrm{Pt}$, the graphitization level and the content of oxygenated functionalities should be optimized not only in terms of proper electronic conductivity and stability of the rGO itself, but also to ensure the balance between hydrophobic and hydrophilic properties which in turn affect the dispersion of catalytic centers, the strength of their binding and gas/water transport within the catalytic material [8]. Further, several studies have shown that hybrid systems of two dimensional graphene-based materials with carbon blacks or carbon nanotubes (acting as separators between graphene sheets) allow the preparation of highly porous three dimensional structures with substantially improved mass transport and durability [9-17]. It should be remembered that expansion of the d-spacing of the graphene layers in graphene nanosheets was also observed after assembling with carbon nanotubes or fullerene C60 [18]. Such composites, when applied as supports for Pt nanoparticles, have considerably increased the utilization of metallic centers during oxygen electroreduction also by improving the stability of the catalysts [13-17].

There have been some attempts of application of iridium and iridium (IV) oxide as the components of cathodic materials in polymer electrolyte membrane fuel cells (PEMFCs). Although their intrinsic activity is far away from the platinum-based catalysts, they have been effectively utilized as additives to platinum [19-38]. In this regard, depending on the route of coupling of Ir-based systems with $\mathrm{Pt}$, different effects and mechanisms of their functioning were elucidated. Better efficiency of some $\mathrm{Pt}-\mathrm{Ir}$ composites (alloys, core-shells, monolayers, sputtered films) [20-28], relative to unmodified Pt counterparts, was attributed to such effects as: (i) the increase of the $\mathrm{Pt} 5 \mathrm{~d}$ vacancy resulting in increased $\mathrm{O}_{2}$ adsorption and weakening the $\mathrm{O}-\mathrm{O}$ double bond and (ii) lowering the coverage of $\mathrm{Pt}$ with $\mathrm{OH}$ as a result of lateral repulsion between the $\mathrm{OH}$ or $\mathrm{O}$ adsorbed on $\mathrm{Ir}$ and the $\mathrm{OH}$ adsorbed on a neighboring $\mathrm{Pt}$ atom. On the other hand, on the basis of the experiments conducted with carbon-supported core-shell structures and DFT calculations, it has been revealed that sole Ir core causes too strong contraction in $\mathrm{Pt}-\mathrm{Pt}$ bonding and thus too weak binding energy of oxygen to $\mathrm{Pt}$ to dissociate it, therefore lower activity of $\mathrm{Pt}$ [29]. Furthermore, the decreased ORR efficiency was observed for physical mixtures of $\mathrm{Pt} / \mathrm{TiO}_{2}$ and $\mathrm{Ir} / \mathrm{TiO}_{2}$, relative to pure $\mathrm{Pt} / \mathrm{TiO}_{2}$ [30].

To date, the detailed investigation on the possible changes in ORR selectivity (toward water or hydrogen peroxide production) due to coupling of $\mathrm{Pt}$ with Ir has not been systematically addressed. Recently, it has been shown that Ir nanostructures, despite their lower efficiency (in comparison to $\mathrm{Pt}$ ), are more selective toward the 4-electron ORR pathway [31,39] and, what should be noted, they can 
promote the selectivity of $\mathrm{Pt}$ toward production of water. The effect has been ascribed to higher population of $\mathrm{Pt}$ active sites free of oxygen-based adsorbates [31].

Regarding the feasibility of utilization of $\mathrm{IrO}_{2}$, there is general agreement in the literature that, regardless of the preparation method (physical mixing of $\mathrm{Pt}$ and $\mathrm{IrO}_{2}$, or deposition of $\mathrm{Pt}$ nanoparticles onto Ir-oxide support), the platinum activity decreases toward oxygen reduction in relation to unmodified $\mathrm{Pt}$ [32-38]. It should be noted that the synthetized system of $\mathrm{Pt} / \mathrm{IrO}_{2}$ has been found to be less efficient than the physical mixture of $\mathrm{Pt}$ and $\mathrm{IrO}_{2}$ blacks. The observation has been ascribed to the stronger interfacial interactions of Ir-oxides with Pt surfaces in the previous case [33].

Finally, it has been also suggested that addition of $\mathrm{Ir}$ or $\mathrm{IrO}_{2}$ to the cathodic materials of fuel cells may considerably improve their durability $[19,24,27,28,30,34-38,40]$, wherein the stability of $\mathrm{IrO}_{2}$ was reported to be higher than that of metallic iridium [41]. It was proposed that these highly efficient oxygen evolution reaction catalysts suppress the electrochemical carbon corrosion due to decomposition of water around the carbon supports at high potentials [36-38].

In the present work, we propose and describe a hybrid system composed of the reduced graphene oxide-supported platinum aligned with multiwalled-carbon-nanotube-supported iridium (both noble metals, $\mathrm{Pt}$ and Ir, are utilized at low loadings, namely on the levels of 15 and $\leq 2 \mu \mathrm{g} \mathrm{cm}^{-2}$, respectively) as catalytic materials for the reduction of oxygen in acid medium $\left(0.5-\mathrm{mol} \mathrm{dm}^{-3} \mathrm{H}_{2} \mathrm{SO}_{4}\right)$. The role of carbon nanotubes is to improve charge distribution at the electrocatalytic interface and facilitate the transport of oxygen and electrolyte in the catalytic systems by lowering the extent of reduced graphene oxide restacking during slow solvent evaporation. Another important issue is the ability of the proposed carrier (carbon nanotubes decorated with Ir) to act as an efficient system for the decomposition of the hydrogen peroxide intermediate generated when a Pt catalyst is utilized at low loading. The rotating ring-disk voltammetric (RRDE) diagnostic experiments reveal that in iridium-containing systems, not only higher disk currents, but also somehow smaller ring currents have been produced (compared to reduced graphene oxide-supported platinum), clearly implying formation of lower amounts of the undesirable hydrogen peroxide intermediate.

\section{Results and Discussion}

Reduced graphene oxide-supported platinum (Pt/rGO) and multiwalled carbon nanotube-supported iridium (Ir/CNT) were combined to form the hybrid (mixed) system with weight ratio of $\mathrm{Pt} / \mathrm{rGO}$ to $\mathrm{Ir} / \mathrm{CNT}$ equal to 2:1 (Pt/rGO+Ir/CNT(2:1)); translating to the atomic ratio of $\mathrm{Pt}$ to Ir ca. 1:0.1. In principle, we were looking for the system containing relatively small amounts of Ir (relative to Pt) because Ir was an expensive component and was known to effectively induce the reductive decomposition of hydrogen peroxide intermediate (rather than ORR itself). Furthermore, the diagnostic RRDE measurements showed the relatively higher activity of the proposed system relative to those having the ratios of $\mathrm{Pt}$ to Ir on the levels 1 to 0.05 or 1 to 0.15 . The optimum catalyst and its components were examined using transmission (TEM) and scanning (SEM) electron microscopies (Figure 1). It is apparent from Figure 1A, $\mathrm{A}^{\prime}$ that the diameters of platinum nanoparticles are on the level of about 6-7 nm, but except the areas with homogenous distribution of "single" particles, there are also regions where their agglomerates can be found (inset to Figure $1 \mathrm{~A}, \mathrm{~B}$ ). Figure $1 \mathrm{C}, \mathrm{C}^{\prime}$ illustrates TEM micrograph and histogram of iridium nanoparticles generated onto CNT support. Among important issues is the uniform arrangement of the Ir nanoparticles of low sizes (close to $2 \mathrm{~nm}$ ) and very low degree of agglomeration (which is also evident in SEM image presented in Figure 1D, where no big clusters of nanoparticles could be observed). Figure 1E,F shows the well-mixed nature of the hybrid system $(\mathrm{Pt} / \mathrm{rGO}+\mathrm{Ir} / \mathrm{CNT}(2: 1))$ in the ink with Nafion ${ }^{\circledR}$ indicating that mesoporous structure of CNT may create interfacial voids for better water and gas management and act as spacer preventing the restacking of graphene sheets. 

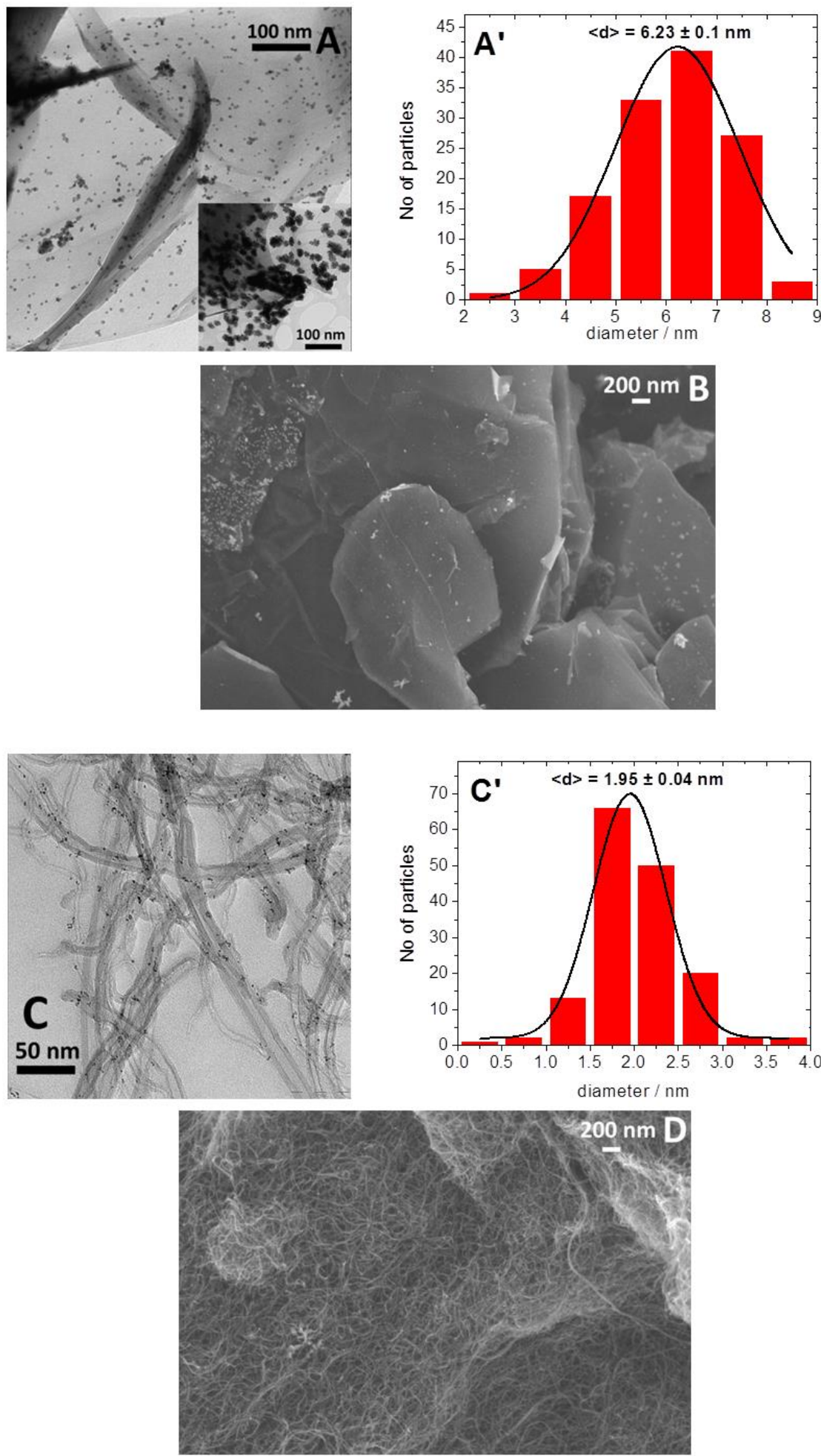

Figure 1. Cont. 

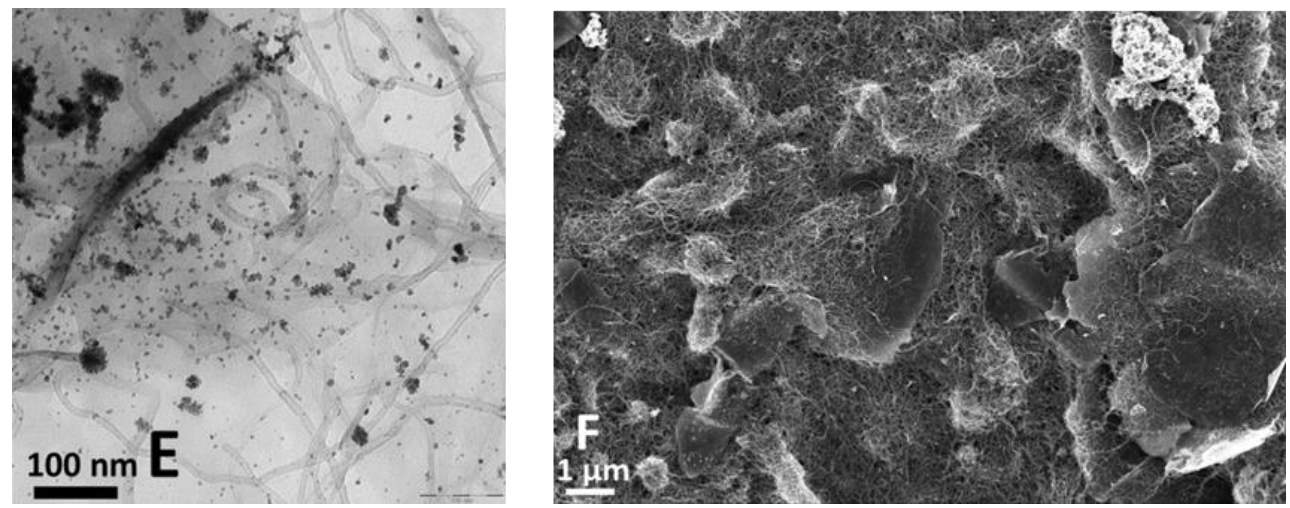

Figure 1. Transmission electron microscopy (TEM) and scanning electron microscopic (SEM) images

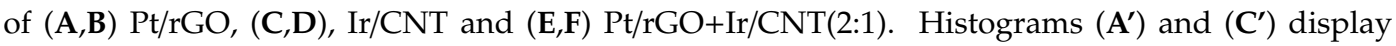
distribution of sizes of $\mathrm{Pt}$ and $\mathrm{Ir}$ nanoparticles.

The approximate compositions of the materials were obtained from the energy-dispersive X-ray (EDX) analysis. For Pt/rGO, the following contents of the main components (in wt $\%$; together with standard deviations) were determined: $\mathrm{C}-65.7 \pm 8.2 \%, \mathrm{O}-7.2 \pm 1.2 \%, \mathrm{Pt}-23.8 \pm 1.0 \%$. On the whole, the amount of platinum in the sample is close to the value expected from the preparation conditions $(20 \%)$, and the appreciable content of oxygen reflects the oxygen functionalities existing at the surface of rGO. The analytical data also revealed the presence of certain amounts of $\mathrm{N}(\sim 2 \%)$, most probably originating from hydrazine reductant and traces of $\mathrm{Na}(\sim 0.5 \%)$ and $\mathrm{S}(\sim 0.1 \%)$. EDX analysis of the Ir/CNT gave the following chemical compositions of the major constituents (in wt $\%$ ): C $-88.0 \% \pm$ $9.7 \%, \mathrm{O}-6.7 \% \pm 1.1 \%$, Ir- $-6.6 \% \pm 0.2 \%$. The small amounts of $\mathrm{Na}(\sim 0.5 \%), \mathrm{Cl}(\sim 0.2 \%)$ and $\mathrm{S}(\sim 0.2 \%)$ have also been detected. The approximately twofold lower than the nominal $(10 \%)$ content of iridium implies incomplete reduction of the precursor under applied conditions. Most likely, this observation should be correlated with the predominant role of CNTs during the reductive deposition. The oxygen functionalities, which are present at the oxidized portions of CNTs, act presumably as nucleation sites for spontaneous deposition of Ir. Similar observations for $\mathrm{Au}, \mathrm{Pd}, \mathrm{Pt}, \mathrm{Rh}$ spontaneously deposited onto SWNTs or GO were reported previously [42-45].

Figure 2 shows the results of $X$-ray powder diffraction (XRD) experiments conducted for the $\mathrm{Pt} / \mathrm{rGO}$ and $\mathrm{Ir} / \mathrm{CNT}$ samples. The XRD pattern of the $\mathrm{Pt} / \mathrm{rGO}$ catalyst (Figure $2 \mathrm{~A}$ ) exhibits a broad peak at $24.5^{\circ}$ corresponding to (002) reflection of carbon and two small peaks at $42.3^{\circ}(10)$ and $78.1^{\circ}(110)$ indicating a short range order in stacked graphene layers [46]. The pattern contains also face centered cubic Pt peaks: (111), (200), (220), (311), (222), (400), (331) and (420) at $2 \theta$ values of $39.8^{\circ}, 46.3^{\circ}, 67.5^{\circ}$, $81.3^{\circ}, 85.8^{\circ}, 103.6^{\circ}, 117.8^{\circ}$ and $122.9^{\circ}$, respectively. The average crystallite size, determined from the peak (220) using Scherrer equation [47], is $7 \mathrm{~nm}$ and is consistent with the results form TEM experiments. The XRD pattern of Ir/CNT (Figure 2B) presents diffraction peaks near $26^{\circ}(002), 44^{\circ}(100)$, $54^{\circ}(004)$ and $78^{\circ}(110)$ characteristic of hexagonal structure of graphite in carbon nanotubes [48]. The peaks characteristic of face centered cubic crystalline iridium at about $41^{\circ}, 47^{\circ}, 69^{\circ}$ and $84^{\circ}$ should be ascribed to the (111), (200), (220) and (311) planes, respectively [39]. Low intensity of Ir signals and their high full width at half maximum (fwhm) suggest exceptionally low size of crystallites and their low crystallinity. Therefore, the average crystallite size- $2.1 \mathrm{~nm}$ - estimated from Scherrer equation (from the peak (111)) should be treated with caution; however, the data quite well agree with TEM microscopy (Figure 1C). 

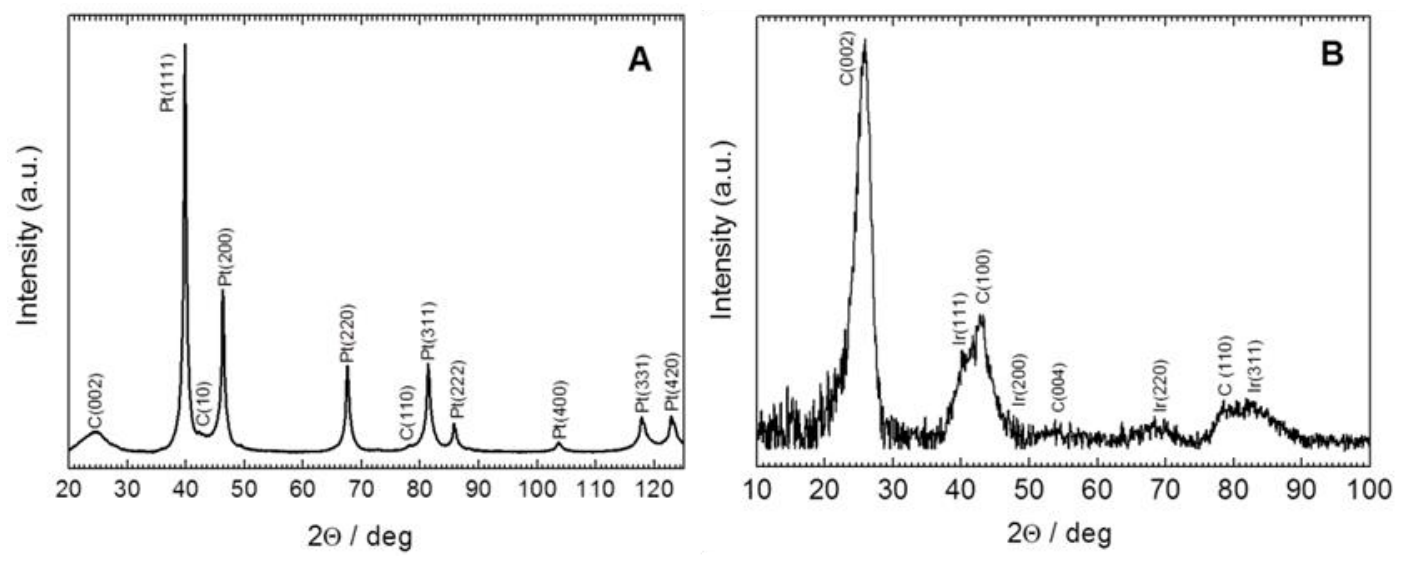

Figure 2. X-ray powder diffraction (XRD) patterns of Pt/rGO (A) and Ir/CNT (B) materials.

To get insight into the chemical nature of platinum and iridium species in Pt/rGO and Ir/CNT we have performed the X-ray photoelectron spectroscopy (XPS) measurements. Figure $3 \mathrm{~A}$ presents the $\mathrm{Pt}$ $4 \mathrm{f} X \mathrm{PS}$ region recorded for $\mathrm{Pt} / \mathrm{rGO}$ sample. The decomposition revealed two distinct components of the $\mathrm{Pt} 4 \mathrm{f}$ with their spin-orbit splitting-resulting counterparts. The splitting resulting from the fitting procedure is consistent with the available literature data, i.e., $3.35 \mathrm{eV}$ [49]. The lower binding-energy component can be ascribed to Pt signal originating from metallic nanoparticles [49]. For this reason, this particular component was fitted with slight asymptotic blend usual for metal representation. The second component shall be recognized as a signal originating from oxidized Pt. The small amount of the oxidized platinum is not surprising since $\mathrm{Pt}$ is known from low ratio of intrinsic oxidation [50]. The scan of the $\mathrm{O} 1 \mathrm{~s}$ region (inset to Figure 3A) confirms existence of the oxygen-metal bond as represented by a lower binding energy component. The higher binding energy component in $\mathrm{O} 1 \mathrm{~s}$ spectrum shall be assigned to organic/ambience adsorption-related species. However, due to lower sensitivity of this particular region, the signal overlap of residual C-O-C configuration signal with $\mathrm{O}-\mathrm{Pt}$ component is highly probable. Therefore, this region shall be treated as a supporting only. Figure 3B,C presents the XPS regions of Ir $4 \mathrm{f}$ and O 1s, respectively, recorded for Ir/CNT sample. Decomposition of the Ir $4 \mathrm{f}$ region reveals two doublets resulting from spin-orbit splitting of $4 \mathrm{f}$ XPS line. The peaks of the first doublet (located at 61.5 and $64.7 \mathrm{eV}$ ) correspond to $4 \mathrm{f}_{7 / 2}$ and $4 \mathrm{f}_{5 / 2}$ lines of metallic form of the iridium. This particular component was fitted with Gaussian/Lorentzian product formula modified by the exponential blend. The binding energies of the second doublet (63.5 and $66.7 \mathrm{eV}$ ) should be ascribed to Ir-O bond $[27,40]$. The peak positions for both: metallic and oxidized iridium are consistent with other literature findings [51]. The relative intensity between metallic Ir and oxidized Ir components $\left(\mathrm{Ir}_{\text {metal }} / \mathrm{Ir}_{\text {oxide }}=2.49\right)$ points that only a little bit less than $1 / 3$ of the overall iridium amount was oxidized. This is highly probable, since the iridium creates agglomerates which are oxidized only at their surface leaving the core area unaltered in its metallic form. The iridium is known from its high affinity to oxygen species; therefore the results are consistent with the view that small nanoparticles (as evident form TEM and XRD analyses) are prone to surface oxidation under exposure to air. As a confirmation to above statement the inset to Figure 3B presents the Ir- $4 \mathrm{f}$ region for control sample containing nominal $2 \%$ of Ir (prepared in the same manner as the one with nominal 10\% of Ir). The decomposition revealed, according to peak binding energy position, that the whole amount of the iridium is present in its oxidized form [51]. Since from additional TEM experiments (data not shown) we could observe that for the nominal $2 \%$ sample the Ir agglomerates were of significantly smaller dimensions, we assume that the whole volume of iridium was penetrated by oxidizing agents. Analysis of $\mathrm{O} 1 \mathrm{~s}$ spectrum (Figure 3C) reveals three components at the binding energies of 531, $532.1 \mathrm{eV}$ and $533.6 \mathrm{eV}$ out of which two first shall be attributed to $\mathrm{O}-\mathrm{Ir}$ and $\mathrm{C}-\mathrm{O}$ bonds existing on the carbon support [52]. The third component is most likely originating from surface functionalities (like-COOH) present on oxidized CNT surface. The inset to Figure $3 \mathrm{C}$ presents the $\mathrm{O} 1 \mathrm{~s}$ region of control nominal 
$2 \%$ sample. The relation in intensities between $\mathrm{C}-\mathrm{O}$ components and $\mathrm{O}-\mathrm{Ir}$ components for nominal $2 \%$ and $10 \%$ samples supports previous statement on iridium oxidation form.
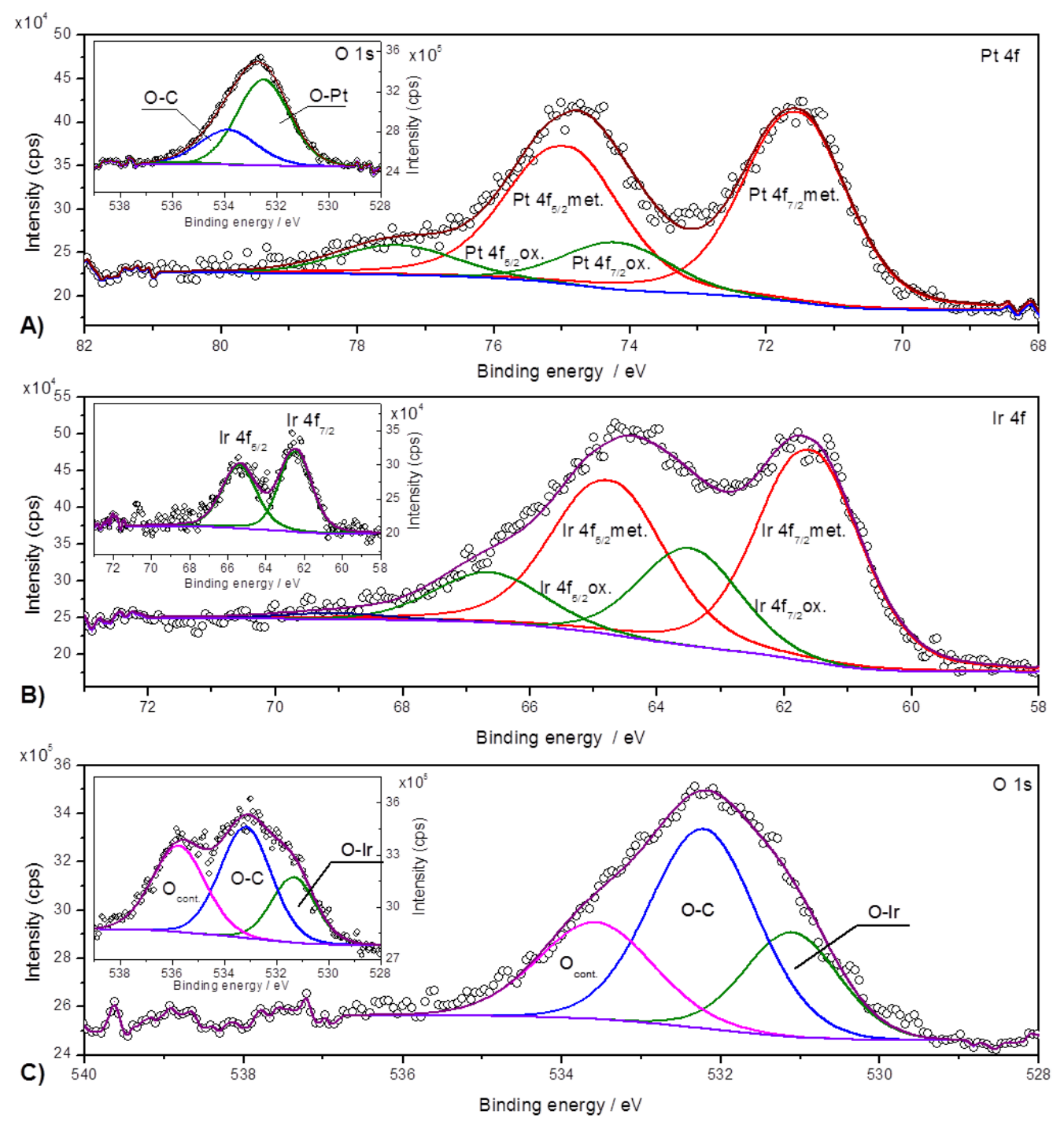

Figure 3. X-ray photoelectron spectroscopy (XPS) spectra of the Pt $4 \mathrm{f}$ and $\mathrm{O} 1 \mathrm{~s}$ regions recorded for (A) $\mathrm{Pt} / \mathrm{rGO}$, (B) Ir $4 \mathrm{f}$ and (C) O 1s regions recorded for the $\mathrm{Ir} / \mathrm{CNT}$. Insets to panels $(\mathbf{B}, \mathbf{C})$ present the $\operatorname{Ir} 4 \mathrm{f}$ and $\mathrm{O} 1$ s regions recorded for $2 \%$-Ir control sample.

Figure 4A shows cyclic voltammetric response of Ir/CNT layer deposited on glassy carbon electrode (solid line) in the deaerated $0.5-\mathrm{mol} \mathrm{dm}^{-3} \mathrm{H}_{2} \mathrm{SO}_{4}$ solution. The peaks observed at potentials below $0.35 \mathrm{~V}$, characteristic to adsorption/desorption of hydrogen atoms at the metal surface and surface oxide/hydroxide formation (starting just above the hydrogen region) are typical for Ir nanostructures [39,53-56]. The cyclic voltammogram of unmodified CNT (dotted line in Figure 4A) reveals the presence of a pair of broad peaks (near $0.6 \mathrm{~V}$ ) that reflect electroactivity of oxygen functionalities present on activated (by $\mathrm{HNO}_{3}$ ) carbon nanotubes. Cyclic voltammograms of $\mathrm{Pt} / \mathrm{rGO}$ and hybrid $\mathrm{Pt} / \mathrm{rGO}+\mathrm{CNT}(2: 0.95)$ and $\mathrm{Pt} / \mathrm{rGO}+\mathrm{Ir} / \mathrm{CNT}(2: 1)$ systems are presented in Figure 4B. It is apparent that, except double layer charging currents increase, the rise of both hydrogen adsorption/desorption peaks as well as currents related to the formation of surface oxides are observed upon introduction of $\mathrm{Ir} / \mathrm{CNT}$ additive, when compared to $\mathrm{Pt} / \mathrm{rGO}$. 

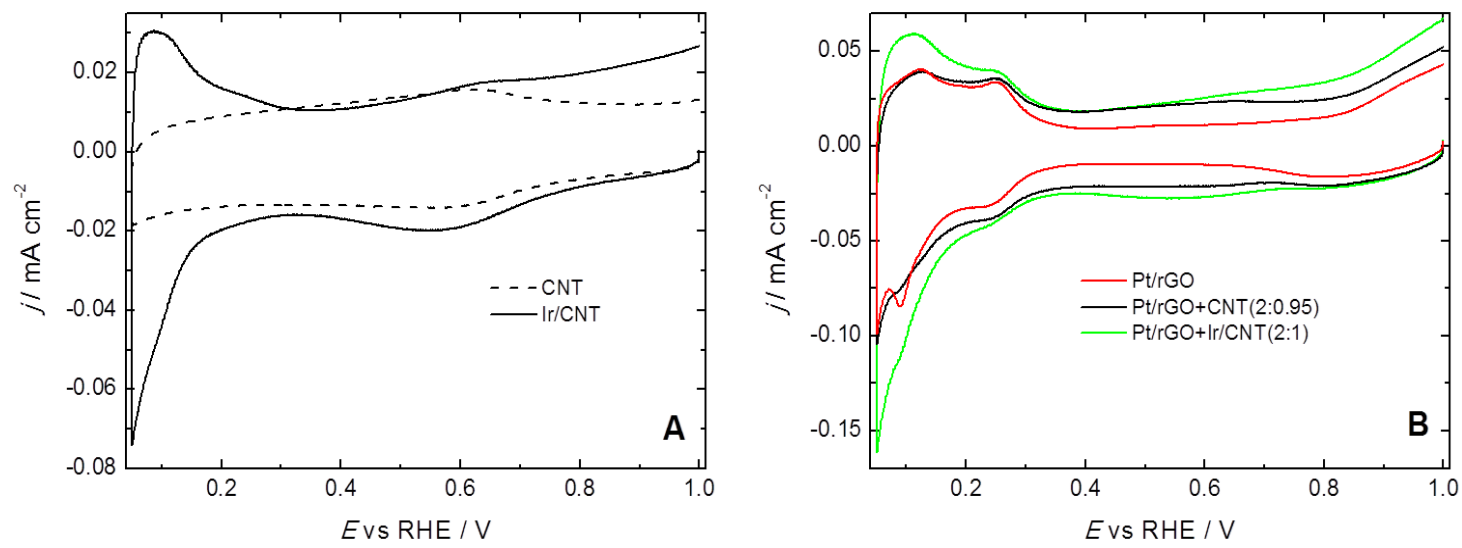

Figure 4. Cyclic voltammetric responses recorded for catalytic films (deposited on glassy carbon disk of RRDE assembly) of CNT and Ir/CNT (A) and Pt/rGO, Pt/rGO+CNT(2:0.95) and Pt/rGO+Ir/CNT(2:1)

(B). Electrolyte: nitrogen-saturated $0.5-\mathrm{mol} \mathrm{dm}^{-3} \mathrm{H}_{2} \mathrm{SO}_{4}$; scan rate: $10 \mathrm{mV} \mathrm{s}^{-1}$.

Figure 5 illustrates representative voltammetric disk (A) and simultaneous amperometric ring (B) currents recorded at rotating ring-disk electrode (RRDE) during the reduction of oxygen, using bare $\mathrm{Pt} / \mathrm{rGO}$ and the hybrid catalysts.
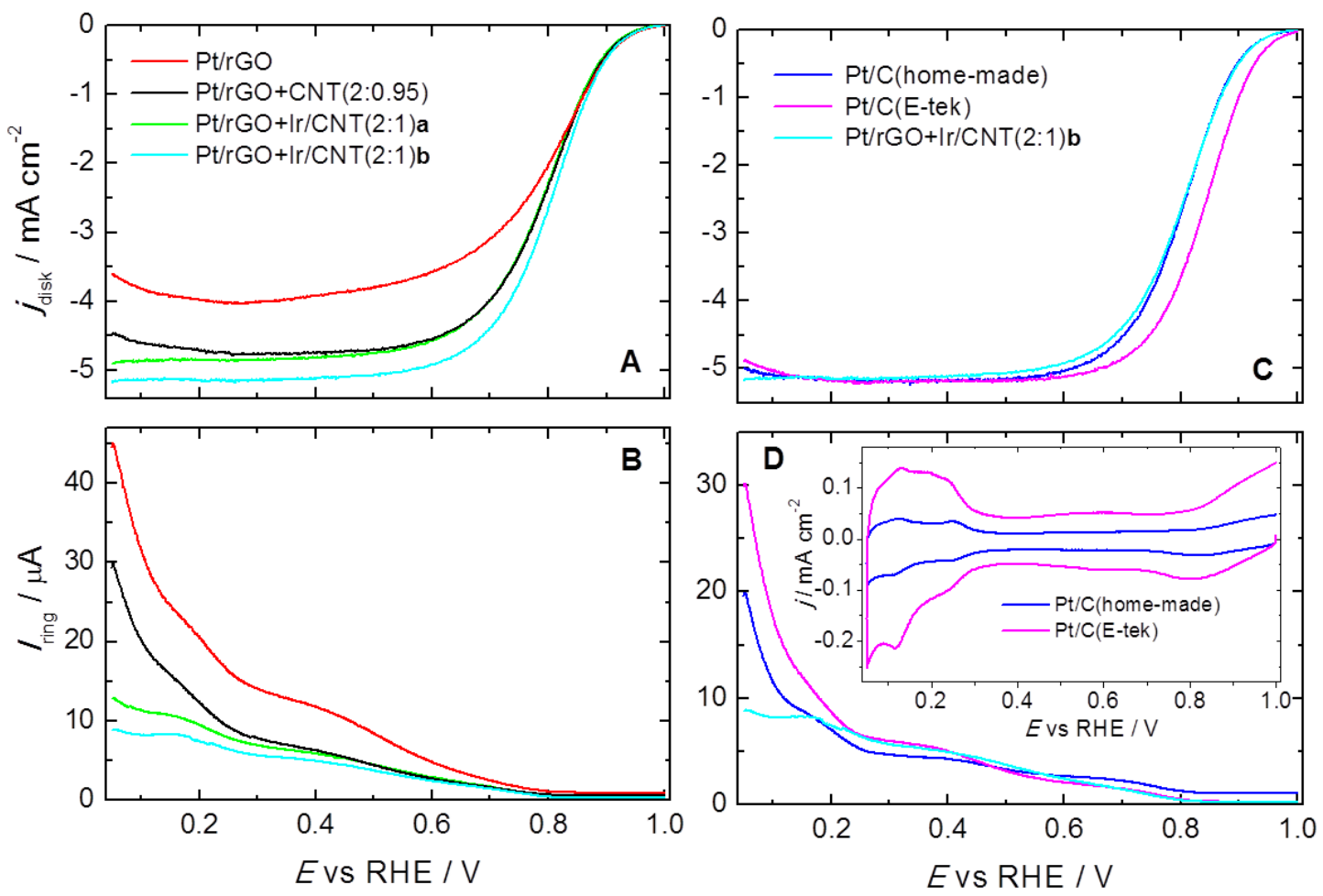

Figure 5. Normalized (background subtracted) rotating disk $(\mathbf{A}, \mathbf{C})$ and ring $(\mathbf{B}, \mathbf{D})$ voltammograms recorded during oxygen reduction at the catalytic films (described in the text) in oxygen-saturated $0.5-\mathrm{mol} \mathrm{dm}^{-3} \mathrm{H}_{2} \mathrm{SO}_{4}$ at the scan rate of $10 \mathrm{mV} \mathrm{s}^{-1}$ and rotation rate of $1600 \mathrm{rpm}$. Inset to Figure 5D shows cyclic voltammetric responses recorded for $\mathrm{Pt} / \mathrm{C}$ (home-made) and $\mathrm{Pt} / \mathrm{C}$ (E-tek) catalysts in nitrogen-saturated $0.5-\mathrm{mol} \mathrm{dm}{ }^{-3} \mathrm{H}_{2} \mathrm{SO}_{4}$ at the scan rate of $10 \mathrm{mV} \mathrm{s}^{-1}$.

It should be mentioned here that, in order to obtain considerable homogeneity of the mixed Pt/rGO+CNT(2:0.95) and Pt/rGO+Ir/CNT(2:1) systems (which was still far from perfect, in comparison to standard (commercial) Vulcan-supported-Pt) and, consequently, their good performance, homogenization in ultrasonic bath and fast deposition onto working electrode was 
required. Otherwise, the presence of CNTs in hybrid systems led to highly irreproducible results and, in some cases even, could result in worse efficiency, when compared to bare Pt/rGO. The most likely reason for some differences in activity and selectivity is high tendency of CNTs to agglomerate and create the tangled network. Furthermore, the differences in hydrophilic/hydrophobic properties of two carbon supports (rGO and CNTs) limit their good mixing. Yet, if the inks were properly homogenized, then disk currents were reproducible within $\pm 4 \%$. Therefore, in Figure $5 \mathrm{~A}, \mathrm{~B}$, next to the most representative results obtained for $\mathrm{Pt} / \mathrm{rGO}$ and $\mathrm{Pt} / \mathrm{rGO}+\mathrm{CNT}(2: 0.95)$, two extreme results obtained for $\mathrm{Pt} / \mathrm{rGO}+\mathrm{Ir} / \mathrm{CNT}(2: 1)$ are given (marked as $\mathrm{Pt} / \mathrm{rGO}+\mathrm{Ir} / \mathrm{CNT}(2: 1)$ a and $\mathrm{Pt} / \mathrm{rGO}+\mathrm{Ir} / \mathrm{CNT}(2: 1) \mathrm{b})$. It is evident from Figure 5A that the disk current densities have substantially increased in a case of the system containing carbon nanotubes $\mathrm{Pt} / \mathrm{rGO}+\mathrm{CNT}(2: 0.95)$, when compared to the bare $\mathrm{Pt} / \mathrm{rGO}$ catalyst. This observation may imply that the addition of CNTs not only improves charge distribution at the electrocatalytic interface but also facilitates the transport of oxygen and electrolyte in the layer by lowering the extent of rGO restacking during slow solvent evaporation (when the layer dries at room temperature). Decreased ring currents (Figure 5B) may suggest that, due to higher thickness of the catalytic layer (upon introduction of CNTs), larger amounts of $\mathrm{H}_{2} \mathrm{O}_{2}$ intermediate are entrapped inside, where they undergo further reduction/decomposition steps and do not reach the ring detector. It is also apparent from Figure $5 \mathrm{~A}, \mathrm{~B}$ that at iridium-containing system $\mathrm{Pt} / \mathrm{rGO}+\mathrm{Ir} / \mathrm{CNT}(2: 1)$ a the disk currents are similar to $\mathrm{Pt} / \mathrm{rGO}+\mathrm{CNT}(2: 0.95)$, but somehow reduced ring currents were produced, implying formation of lower amounts of the undesirable $\mathrm{H}_{2} \mathrm{O}_{2}$ intermediate after introduction of traces of Ir. The results obtained for Pt/rGO+Ir/CNT(2:1)b (Figure 5A,B) suggest that much greater efficiency and selectivity toward 4-electron oxygen reduction is possible. By comparing the RRDE curves recorded for $\mathrm{Pt} / \mathrm{rGO}+\mathrm{Ir} / \mathrm{CNT}(2: 1) \mathrm{b}$ system with those recorded for Vulcan-supported-Pt $(\mathrm{Pt} / \mathrm{C}$ (home-made)), synthesized with the same manner as $\mathrm{Pt} / \mathrm{rGO}$, one can observe similar catalytic activity toward ORR (Figure 5C,D). At commercial Pt/C (Vulcan-supported-Pt from E-tek company), the potential of the process is shifted of around $40 \mathrm{mV}$ toward more positive values which most likely results from much smaller Pt nanoparticles (around $4 \mathrm{~nm}$ ) and, therefore, higher roughness factor of the electrode surface [57]. Here, somewhat larger ring currents (corresponding to larger amounts of $\mathrm{H}_{2} \mathrm{O}_{2}$ intermediate produced) were observed at commercial $\mathrm{Pt} / \mathrm{C}$ in the region of hydrogen adsorption/desorption at the noble metal surface. Indeed, it is apparent from the voltammetric responses, recorded in $\mathrm{N}_{2}$-saturated electrolyte (Inset to Figure 5D), that the electrochemically active surface area of $\mathrm{Pt}$ is much higher for $\mathrm{Pt} / \mathrm{C}$ (E-tek) when compared to $\mathrm{Pt} / \mathrm{C}$ (home-made). Higher hydrogen adsorption/desorption signals observed for Pt/C (E-tek) suggest that more Pt catalytic sites may be occupied by hydrogen atoms, which are competitive to oxygen molecules, resulting in site-blocking effect. Therefore, the selectivity of the oxygen reduction toward formation of water may be somehow lower in this potential region for $\mathrm{Pt} / \mathrm{C}$ (E-tek). Moreover, it is reasonable to expect that the differences in structural properties may influence the adsorption capacity of the samples (e.g., hydrogen, hydroxyl, sulfate/bisulfate ions, impurities).

To estimate percentage of $\mathrm{H}_{2} \mathrm{O}_{2}\left(\mathrm{X}_{\mathrm{H}_{2} \mathrm{O}_{2}}\right)$ produced during oxygen reduction at catalytic films and average number of electrons $\left(\mathrm{n}_{\mathrm{e}}\right)$ participating in the electrocatalytic reaction, we have used the equations given below [58-60]:

$$
\begin{aligned}
\mathrm{X}_{\mathrm{H}_{2} \mathrm{O}_{2}} & =\frac{2 \mathrm{I}_{\mathrm{R}} / \mathrm{N}}{\left|\mathrm{I}_{\mathrm{D}}\right|+\mathrm{I}_{\mathrm{R}}} \times 100 \% \\
\mathrm{n}_{\mathrm{e}} & =\frac{4\left|\mathrm{I}_{\mathrm{D}}\right|}{\left|\mathrm{I}_{\mathrm{D}}\right|+\mathrm{I}_{\mathrm{R}} / \mathrm{N}}
\end{aligned}
$$

In the Equations (1) and (2) $I_{R}$ is ring current, $I_{D}$ is disk current and $N$ is the collection efficiency of the RRDE assembly. It becomes apparent from Figure 6, where $\mathrm{X}_{\mathrm{H} 2 \mathrm{O} 2}$ and $\mathrm{n}_{\mathrm{e}}$ both plotted versus potential applied to the disk electrode are presented, that the selectivity of the process toward 4-electron reduction (with formation of water as the major product) is increased in the presence of Ir additive. 

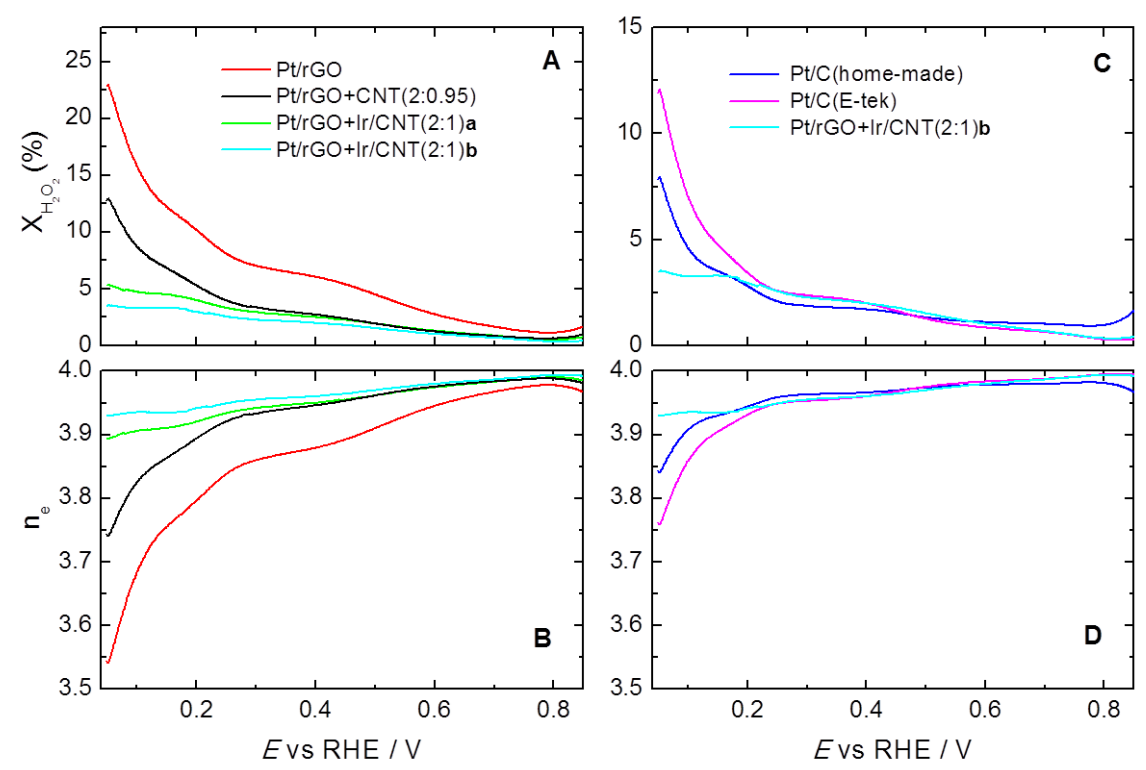

Figure 6. Formation of $(\mathbf{A}, \mathbf{C})$ the hydrogen peroxide intermediate and $(\mathbf{B}, \mathbf{D})$ number of exchanged electrons during oxygen reduction under conditions of rotating ring-disk electrode (RRDE) voltammetric experiments in Figure 5.

When compared to platinum-based materials, iridium nanostructures are considered as relatively weak catalyst toward oxygen reduction [31,39], while their high activity in the electrochemical/chemical decomposition of hydrogen peroxide has been postulated $[39,61]$. Thus, in the next step we have evaluated the Ir/CNT as a potential catalyst of both processes, maintaining the same low loading as in the hybrid system of $\mathrm{Pt} / \mathrm{rGO}+\mathrm{Ir} / \mathrm{CNT}(2: 1)$. The RRDE voltammetric measurements conducted in $\mathrm{O}_{2}$-staurated electrolyte (under the same experimental conditions as those presented in Figure 5) reveal that $\mathrm{Ir} / \mathrm{CNT}$ reduces oxygen at much more negative potentials when compared to Pt-containing systems (starting and half-wave potentials are shifted to lower values of around 0.2 and $0.3 \mathrm{~V}$, respectively, please compare Figures 5A and 7A). Nevertheless, as evident from Figure 7B, observed ring currents are small, indicating high selectivity of the compound toward production of water. The percentage amount of $\mathrm{H}_{2} \mathrm{O}_{2}$ produced is at the same level as for Pt-containing hybrid systems (please compare Figures $6 \mathrm{~A}$ and $7 \mathrm{C})$, in spite of the fact that the loading of active Ir sites is much lower $\left(\sim 1.9 \mu \mathrm{g} \mathrm{cm}^{-2}\right)$ than $\mathrm{Pt}\left(15 \mu \mathrm{g} \mathrm{cm}^{-2}\right)$. Further experiment (Figure $\left.7 \mathrm{D}\right)$, conducted in deoxygenated $0.5-\mathrm{mol} \mathrm{dm}^{-3}$ $\mathrm{H}_{2} \mathrm{SO}_{4}$ with addition of 1-mmol dm${ }^{-3}$ of $\mathrm{H}_{2} \mathrm{O}_{2}$ (i.e., with the concentration similar to the concentration of oxygen in its saturated electrolyte), showed that $\mathrm{H}_{2} \mathrm{O}_{2}$ reduction starts at potentials as high as $0.9 \mathrm{~V}$, that is at least $0.1 \mathrm{~V}$ higher than for $\mathrm{O}_{2}$ reduction, thus implying better efficiency of Ir nanostructures in the former process.

The above observations imply that the enhancement effect coming from the addition of traces of iridium (supported onto CNT) to Pt/rGO (with low Pt loading) may originate from the high ability of Ir to induce decomposition of the undesirable hydrogen peroxide intermediate. The data presented in Figure 7A,B,D also confirm that the mixture of bare carbon supports (rGO and CNTs) does not show any significant activity neither toward oxygen nor hydrogen peroxide reduction relative to $\mathrm{Ir} / \mathrm{CNT}$.

Although catalytic efficiency of $\mathrm{Pt} / \mathrm{rGO}+\mathrm{Ir} / \mathrm{CNT}(2: 1)$ system seems to be promising, our preliminary accelerated durability tests (potential cycling at $50 \mathrm{mV} \mathrm{s}^{-1}$ between $0.6-1 \mathrm{~V}$ vs. RHE without rotation) indicate the gradual decline in activity and loss of iridium. The observation stays in accordance with literature data implying that the dissolution of Ir occurs during transient oxidation and reduction processes and is initialized at potentials of ca. 0.7-1.1 $\mathrm{V}_{\mathrm{RHE}}$ depending on experimental conditions [41,62]. In addition, higher dissolution rate is usually observed for amorphous iridium-based materials than for more crystalline forms [19,41]. Therefore, for future purposes, in order to obtain more stable catalysts, the size and the degree of crystallinity of Ir should be increased. Moreover, the data 
may indicate lower stability of metal nanoparticles onto carbon support caused by homogenization in ultrasonic bath, which on the other hand was necessary to properly homogenize the composite samples.

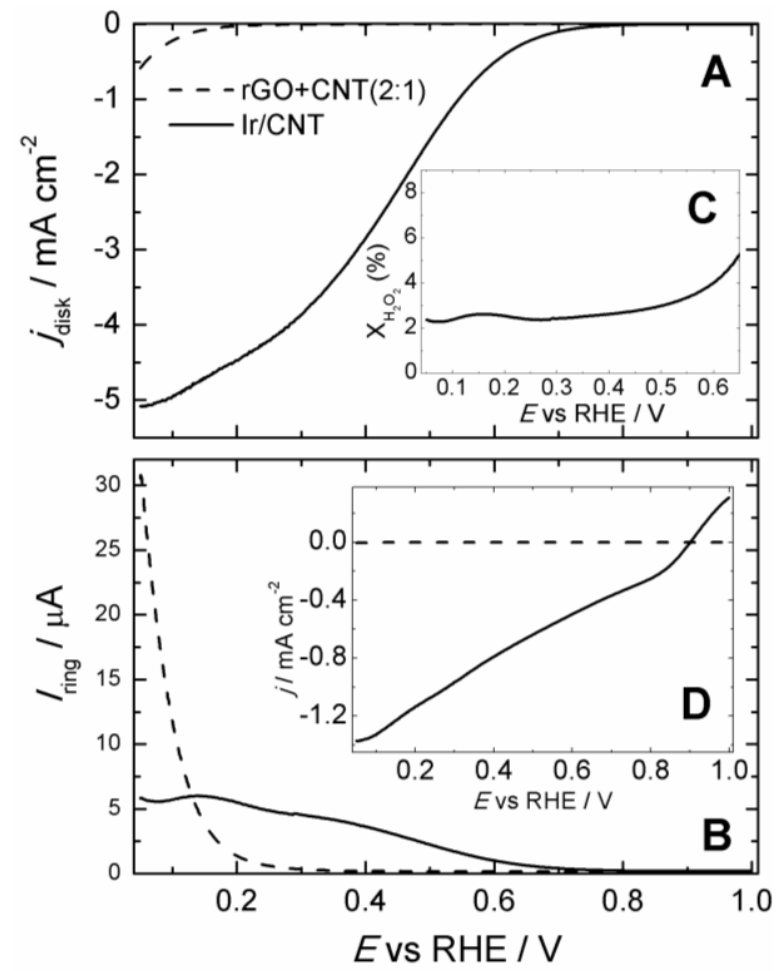

Figure 7. Normalized (A) rotating disk and (B) ring voltammograms recorded during oxygen reduction at the $\mathrm{Ir} / \mathrm{CNT}$ and $\mathrm{rGO}+\mathrm{CNT}(2: 1)$ films in oxygen-saturated $0.5-\mathrm{mol} \mathrm{dm}{ }^{-3} \mathrm{H}_{2} \mathrm{SO}_{4}$ at the scan rate of $10 \mathrm{mV} \mathrm{s}^{-1}$ and rotation rate of $1600 \mathrm{rpm}$; (C) formation of $\mathrm{H}_{2} \mathrm{O}_{2}$ intermediate generated during oxygen reduction at Ir/CNT under conditions of RRDE voltammetric experiment; (D) normalized rotating disk voltammograms recorded at the Ir/CNT and $\mathrm{rGO}+\mathrm{CNT}(2: 1)$ films in nitrogen-saturated $0.5-\mathrm{mol} \mathrm{dm}^{-3}$ $\mathrm{H}_{2} \mathrm{SO}_{4}$ in the presence of 1-mmol dm${ }^{-3} \mathrm{H}_{2} \mathrm{O}_{2}$. Scan rate: $10 \mathrm{mV} \mathrm{s}^{-1}$; rotation rate: $1600 \mathrm{rpm}$.

Finally, we have also performed galvanodynamic measurements with use of gas diffusion electrode (GDE), mimicking the conditions existing in the low-temperature fuel cell. Figure 8 shows typical polarization curves (potential vs. applied current density normalized to Pt mass, i.e., specific current) recorded in the oxygen saturated $0.5-\mathrm{mol} \mathrm{dm}{ }^{-3} \mathrm{H}_{2} \mathrm{SO}_{4}$ at $80{ }^{\circ} \mathrm{C}$ following deposition of $\mathrm{Pt} / \mathrm{rGO}$ and hybrid system Pt/rGO+Ir/CNT(2:1). The superior performance of the Ir-containing system appears at higher current densities. It is evident from Figure 8 that with the increase of specific current, up to the region where mass transport should dominate, higher half-cell potentials are produced at the hybrid $\mathrm{Pt} / \mathrm{rGO}+\mathrm{Ir} / \mathrm{CNT}(2: 1)$ system. The data of Figure 8 are in fairly good agreement (in terms of quality) with the results of diagnostic RDE experiments (Figure 5A), again indicating the favorable transport of reagents and electrolyte in the composite layer containing both Pt/rGO and Ir/CNT. Nevertheless, the activation effect is less visible in the case of GDE measurements.

The data presented here reveal that differences in the methodology for the preparation of catalytic layers and test conditions can have a large impact on the assessment of the final catalytic performance of systems containing rGO as a substrate. It seems that the homogeneity of the catalytic layers, and most likely the lowering of the extend of restacking of $\mathrm{rGO}$, is much better using spray-coating (with fast evaporation of the solvent at elevated temperature for GDE testing) compared to drop-casting (with slow evaporation of solvent at room temperature for RRDE testing). 


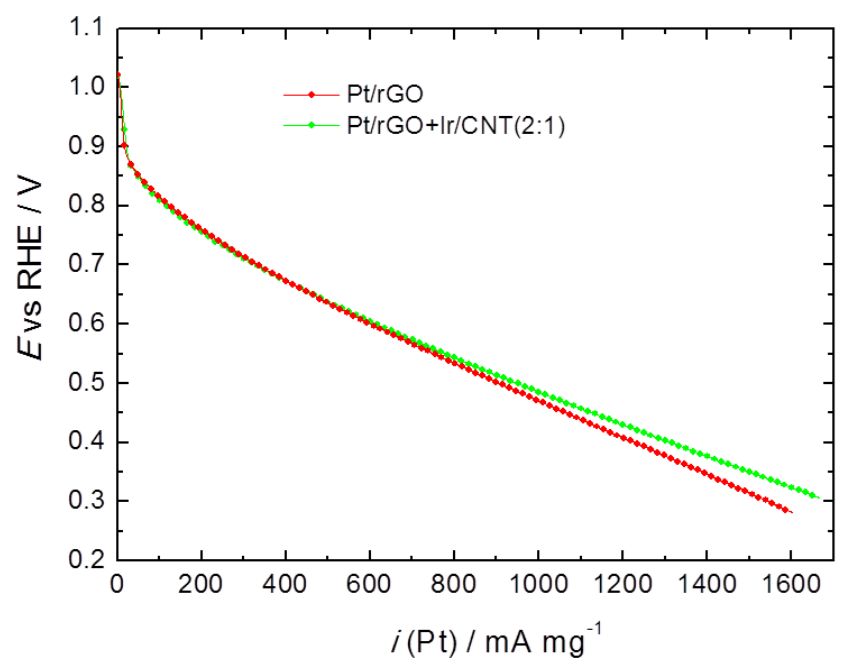

Figure 8. Galvanodynamic steady-state polarization responses for the oxygen reduction on gas diffusion electrodes. Oxygen flux: $50 \mathrm{~mL} \mathrm{~min}^{-1}$; temperature: $80^{\circ} \mathrm{C}$; electrolyte: oxygen saturated $0.5-\mathrm{mol} \mathrm{dm}^{-3}$ $\mathrm{H}_{2} \mathrm{SO}_{4}$; loading of Pt: $0.05 \mathrm{mg} \mathrm{cm}{ }^{-2}$.

\section{Materials and Methods}

\subsection{Chemicals}

All chemicals were commercial materials of the highest available purity. Quantities of 2-propanol, $\mathrm{HNO}_{3}, \mathrm{H}_{2} \mathrm{SO}_{4}, \mathrm{KOH}$ were purchased from POCh (Poland), the solution of 5-wt $\%$ Nafion-1100, platinum potassium hexachloroplatinate $\left(\mathrm{K}_{2} \mathrm{PtCl}_{6}\right)$, multi-walled carbon nanotubes (O.D. $\times$ I.D. $\times \mathrm{L} 10 \mathrm{~nm} \times$ $4.5 \mathrm{~nm} \times 3-6 \mu \mathrm{m}$ ) from Sigma Aldrich, iridium(III) chloride hydrate from Alfa Aesar. Nitrogen and oxygen gases (purity, 99.999\%) were from Air Products (Poland). The solutions for electrochemical experiments were prepared from doubly distilled and subsequently deionized (Millipore Milli-Q) water. Multiwalled carbon nanotubes (CNT) were activated in 2-mol dm ${ }^{-3} \mathrm{HNO}_{3}$ under reflux for $2 \mathrm{~h}$ and washed with water until $\mathrm{pH}$ was near 6.

\subsection{Materials Preparation}

Graphene oxide (GO) was prepared using a modified Hummer's method from commercial graphite powder (ACROS ORGANICS). In this process, $10 \mathrm{~g}$ of graphite powder was added to $230 \mathrm{~mL}$ of concentrated sulfuric acid (98 wt\%) and stirred for $30 \mathrm{~min}$. Next, $4.7 \mathrm{~g}$ sodium nitrate and $30 \mathrm{~g}$ potassium permanganate was slowly added to the mixture and the temperature was kept below $10^{\circ} \mathrm{C}$ in an ice bath. Then the mixture was slowly heated up to $\sim 33^{\circ} \mathrm{C}$ and was controlled so as not to exceed $35^{\circ} \mathrm{C}$ for $2 \mathrm{~h}$ under stirring. In the next step, $100 \mathrm{~mL}$ of water was added to the mixture and the temperature reached $\sim 120{ }^{\circ} \mathrm{C}$. Finally, the mixture was treated with $10 \mathrm{~mL}$ of $\mathrm{H}_{2} \mathrm{O}_{2}(30 \mathrm{wt} \%)$. Obtained slurry was kept in an ultrasonic bath for $1 \mathrm{~h}$. For purification, the slurry was filtered using ceramic membranes with 0.2-micron pore size and washed with deionized water in order to remove the byproducts of the synthesis till the $\mathrm{pH}$ of the filtrate reached 6.5.

Reduced graphene oxide (rGO) was obtained in the course of the hydrazine reduction method in an analogous manner as described in ref [46]. In brief, $10 \mathrm{~mL} \mathrm{50 \%} \mathrm{hydrazine} \mathrm{water} \mathrm{solution} \mathrm{was}$ added to $100 \mathrm{~mL} 0.5-\mathrm{wt} \%$ GO water dispersion. The mixture was heated up to $100{ }^{\circ} \mathrm{C}$ and kept under stirring for $2 \mathrm{~h}$. After reduction, the product was filtered using polyethersulfone (PES) filter with $0.8-\mu \mathrm{m}$ pore size.

Reduced graphene oxide-supported platinum (Pt/rGO) catalyst (with final Pt loading at the level of $20 \mathrm{wt} \%$ ) was synthetized in the course of the borohydride reduction method as described in ref [48]. Briefly, a proper amount of the Pt precursor $\left(\mathrm{K}_{2} \mathrm{PtCl}_{6}\right)$ was added to $0.5 \mathrm{~g} \mathrm{rGO}$ water dispersion under continuous magnetic stirring. After $15 \mathrm{~min}$, the $0.1-\mathrm{mol} \mathrm{dm}{ }^{-3} \mathrm{KOH}$ was added to the mixture to 
increase the $\mathrm{pH}$ to 10 . Nanoparticles of $\mathrm{Pt}$ were obtained by adding $10 \mathrm{~mL}$ of $1-\mathrm{mol} \mathrm{dm}^{-3} \mathrm{NaBH}_{4}$ water solution to the slurry and kept under stirring. After $1 \mathrm{~h}$ the $20-\mathrm{wt} \% \mathrm{Pt} / \mathrm{rGO}$ catalyst deposit was filtered using PES filter with $0.8-\mu \mathrm{m}$ pore size and washed with deionized water.

The synthesis of carbon nanotube-supported iridium nanoparticles (Ir/CNT) was performed through thermal reduction (under reflux for $2 \mathrm{~h}$ in $\mathrm{N}_{2}$ atmosphere) of $\mathrm{IrCl}_{3}$ in the solution of 2-propanol in the presence of carbon support. Before reflux, the suspension of CNT and solution of $\mathrm{IrCl}_{3}$ were subjected to sonication for $1 \mathrm{~h}$. After synthesis, the sample was washed out with water by centrifugation (3-4 times) and dried on a hot plate at $50{ }^{\circ} \mathrm{C}$. The amounts of $\mathrm{IrCl}_{3}$ and $\mathrm{CNTs}$ were set to obtain $10 \mathrm{wt} \%$ of nominal loading of Ir onto CNTs, but the final Ir loading appeared to be on the level of $5 \mathrm{wt} \%$ (the appropriate comment can be found in the "Results and discussion" section).

\subsection{Equipment and Characterization of Materials}

Electrochemical measurements were performed using CH Instruments (Austin, TX, USA) 920D workstation. A glassy carbon rod served as a counter electrode and the reference electrode was a mercury/mercurous sulfate electrode, $\mathrm{Hg} / \mathrm{Hg}_{2} \mathrm{SO}_{4}$ (all potentials were recalculated and expressed versus the reversible hydrogen electrode (RHE) scale). The rotating ring-disk electrode (RRDE) voltammetric experiments were conducted via variable speed rotator (Pine Instruments, Durham, NC, USA). RRDE assembly included a glassy carbon disk (diameter $5.61 \mathrm{~mm}$ ) and a platinum ring (inner and outer diameters were 6.25 and $7.92 \mathrm{~mm}$, respectively) and its collection efficiency (determined with the procedure reported previously [39]) was equal to 0.39 . Prior the experiments the working electrode was polished with aqueous alumina slurries (grain size $0.05 \mu \mathrm{m}$ ) on a Buehler polishing cloth.

The inks for RRDE studies were prepared by homogenization of the materials (Pt/rGO, Ir/CNT or CNT) with 2-propanol $(5 \mathrm{mg} / 3 \mathrm{~mL})$ and proper amount of Nafion ${ }^{\circledR}$. Due to different densities of carbon supports (rGO and CNT) it was necessary to optimize the content of Nafion ${ }^{\circledR}$ relative to the weight of sample (in terms of the highest possible homogeneity of the layers and obtaining proper ionic conductivity and mass transport). Therefore, for $\mathrm{Pt} / \mathrm{rGO}$ ionomer optimum content was $10 \mathrm{wt} \%\left(12.7 \mu \mathrm{L}\right.$ of Nafion ${ }^{\circledR}$ solution added), for CNT and Ir/CNT $-30 \mathrm{wt} \%\left(49 \mu \mathrm{L}\right.$ of Nafion ${ }^{\circledR}$ solution added). The hybrid (mixed) systems were produced by mixing $\mathrm{Pt} / \mathrm{rGO}$ ink $(500 \mu \mathrm{L})$ with $\mathrm{Ir} / \mathrm{CNT}$ $(253 \mu \mathrm{L})$ or CNT $(240 \mu \mathrm{L})$ inks. The weight ratio of Pt/rGO to Ir/CNT was 2:1 (sample denoted as $\mathrm{Pt} / \mathrm{rGO}+\operatorname{Ir} / \mathrm{CNT}(2: 1)$ ), which corresponds to relative molar ratio of Pt to Ir around 1:0.1 (based on the compositions of materials obtained from the EDX analysis). In the sample denoted as $\mathrm{Pt} / \mathrm{rGO}$ $+\mathrm{CNT}(2: 0.95), \mathrm{Pt} / \mathrm{rGO}$ was mixed with $\mathrm{CNT}$ in the weight ratio of 2:0.95 (to keep the amount of CNTs at nearly the same level as in the $\mathrm{Pt} / \mathrm{rGO}+\mathrm{Ir} / \mathrm{CNT}(2: 1)$ system). During the studies it has been revealed that, regardless of the conditions of homogenization (including (i) only sonication followed by storing the samples overnight and renewed sonication just before deposition of the layers on working electrode or (ii) sonication followed by mixing at magnetic stirrer overnight and renewed sonication just before deposition of the layers on working electrode) the inks and electrocatalytic layers were highly inhomogeneous. What is more, during storing the inks, their composition was changing slightly with time due to uncontrolled settling of sediments onto the walls of vials, therefore there was some irreproducibility of the results, which was evident not only at disk currents, but especially at ring currents which response is very sensitive to the quality of the layers deposited onto disk electrode. The inks were introduced on the GC electrode surface by micropipette and dried at room temperature, $22 \pm 2{ }^{\circ} \mathrm{C}$. The amount of materials casted onto GC electrode was adjusted individually to maintain the same loading of each component, i.e., $\mathrm{Pt}, \mathrm{rGO}$, Ir and CNT. The final $\mathrm{Pt}$ loading was $15 \mu \mathrm{g} \mathrm{cm}{ }^{-2}$. The electrodes-covered with the catalytic layers-were washed out with the stream of water and subjected to potential cycling in the ranges between $0.05 \mathrm{~V}$ and $0.8 \mathrm{~V}$ followed by $0.05 \mathrm{~V}$ and $1 \mathrm{~V}$ (vs. RHE) at the $100-\mathrm{mV} \mathrm{s}^{-1}$ in the $\mathrm{N}_{2}$-saturated 0.1-mol dm ${ }^{-3} 0.5-\mathrm{mol} \mathrm{dm}^{-3} \mathrm{H}_{2} \mathrm{SO}_{4}$ until a stable stationary voltammetric responses were obtained.

The performance of examined catalysts was also tested at $80 \pm 2{ }^{\circ} \mathrm{C}$ with a gas diffusion electrode (GDE, geometric area of active part, $3 \mathrm{~cm}^{2}$ ) mounted into Teflon flex cell (Gaskatel $\mathrm{GmbH}$, 
Kassel, Germany). A spiral PtIr wire and $\mathrm{Hg} / \mathrm{Hg}_{2} \mathrm{SO}_{4}$ electrode (the latter placed in an external salt bridge) served as counter and reference electrodes, respectively. The gas diffusion backing layer for electrocatalysts was a carbon cloth with microporous layer (W1S1005, Fuel Cell Store, College Station, TX, U.S.A.). Catalytic layers were spray coated (using vacuum table heated up to ca. $80{ }^{\circ} \mathrm{C}$ ) from the inks, in which the ratio of catalyst to Nafion ${ }^{\circledR}$ was the same as in the course of RRDE thin film studies, but the mixture of water and 2-propanol (1:1 by volume) was applied as solvent and the level of dilution was higher ( $1 \mathrm{mg}$ of catalytic material per $2 \mathrm{~mL}$ of solvent). Final loading of $\mathrm{Pt}$ was about $50 \mu \mathrm{g} \mathrm{cm}^{-2}$. The current densities were normalized to the exact mass of platinum (determined by weighing the carbon cloth before and after preparation of the layers).

Transmission electron microscopy (TEM) experiments were carried out with Libra 120 EFTEM (Carl Zeiss, Jena, Germany) operating at $120 \mathrm{kV}$. Size measuring of Pt and Ir nanoparticles were conducted using ImageJ free software [63]. Scanning electron microscopic (SEM) measurements and energy-dispersive X-ray analysis were achieved using MERLIN FE-SEM (Carl Zeiss) equipped with EDX probe (Bruker). The X-ray powder diffraction (XRD) spectrum of $\mathrm{Pt} / \mathrm{rGO}$ was measured using Rigaku-Denki X-ray diffractometer (Tokyo, Japan) in a Bragg-Brentano configuration with a $\mathrm{Ni}$-filtered $\mathrm{Cu}$ radiation from a sealed tube operating at $40 \mathrm{kV}$ and $40 \mathrm{~mA}$ stability of $0.01 / 8 \mathrm{~h}$. The XRD pattern of Ir/CNT was collected using Bruker D8 Discover (Berlin, Germany) equipped with a Cu lamp $(1=1.540598 \AA)$ and data were analyzed using EVA and TOPAS 4.2 software. X-ray photoelectron spectroscopy (XPS) investigations were carried out in ultra-high vacuum experimental setup (base pressure $5 \times 10^{-8} \mathrm{~Pa}$ ) equipped with PREVAC EA15 (Rogow, Poland) hemispherical electron energy analyzer with 2D-MCP detector. The samples were irradiated with Al-K $\alpha$ X-ray source (PREVAC dual-anode XR-40B source, energy $1486.60 \mathrm{eV}$ ). The binding energy (BE) scale of the analyzer was calibrated to $\mathrm{Au} 4 \mathrm{f}_{7 / 2}(84.0 \mathrm{eV})$ [64]. Recorded data were fitted utilizing CASA XPS ${ }^{\circledR}$ software [65]. For background subtraction the Shirley function was used. If not specified, the components were fitted with a sum of Gaussian $(70 \%)$ and Lorentzian $(30 \%)$ lines. The full width at half maximum (FWHM) values for the peaks at the same binding energy region were allowed to vary within a narrow range. The estimated uncertainty for components' energy position determination was $0.1 \mathrm{eV}$.

\section{Conclusions}

We demonstrate here that the addition of carbon nanotubes decorated with iridium nanoparticles results in the enhancement of electrocatalytic activity of graphene oxide-supported platinum during the reduction of oxygen in acid medium. The effect is demonstrated in terms of the higher catalytic current densities observed and lower amounts of hydrogen peroxide produced under conditions of rotating ring-disk voltammetric studies. The enhancement effect coming from the addition of traces of iridium (supported onto CNT) to $\mathrm{Pt} / \mathrm{rGO}$ (with low Pt loading) may originate from the high ability of Ir to induce decomposition of the undesirable hydrogen peroxide intermediate. The improved efficiency of the hybrid system (although to lower extend) was confirmed by galvanodynamic measurements conducted at elevated temperature $\left(80^{\circ} \mathrm{C}\right)$ with use of gas diffusion electrode, operating under conditions resembling those characteristic of the cathode in a real fuel cell. In conclusion, the formation of the undesirable $\mathrm{H}_{2} \mathrm{O}_{2}$-type intermediate seems to be decreased through preparation of the multicomponent or multi-functional hybrid catalytic system utilizing two distinct (Pt, Ir) catalytic sites and rGO admixed with CNTs as supports. The results are not only consistent with the view that rGO can be used as carrier for Pt nanoparticles for oxygen reduction in acid media, but also imply the feasibility of using trace amounts of such $\mathrm{H}_{2} \mathrm{O}_{2}$-decomposition catalysts as Ir. On the whole, it is reasonable to expect, as postulated earlier [66] that hybrid structures of graphene admixed with different carbons could be considered as supports also due to possibility of the improved mass transport of reactants, stability and catalytic efficiency. 
Author Contributions: Conceptualization, P.J.K. and B.D.; methodology, B.D., P.J.K., E.N. and V.D.N.; validation, B.D., K.M., M.K., J.Z., E.N. and V.D.N.; formal analysis, B.D. and P.J.K.; investigation, B.D., A.Z., M.M., A.M. and M.K.; resources, B.D., A.Z., K.M., I.A.R., A.M., L.S.; data curation, B.D. and M.K.; writing-original draft preparation, B.D. and P.J.K.; writing of review and editing, B.D. and P.J.K.; visualization: B.D., M.K. and P.J.K.; supervision, P.J.K.; funding acquisition, P.J.K. and V.D.N. All authors have given approval to the final version of the manuscript.

Funding: This work was supported by the National Science Center (NCN, Poland) under Opus Project 2018/29/B/ST5/02,627. We also acknowledge the initial support from European Commission through the Graphene Flagship-Core 1 project [Grant number GA-696656]. This research was further pursued under auspices of the European Union EIT Raw Materials ALPE 19247 Project (Specific Grant Agreement No. EIT/RAW MATERIALS/SGA2020/1).

Acknowledgments: M.K. and J.Z. acknowledge the ESPEFUM laboratory at the Institute of Physics-CSE, Silesian University of Technology for access to the XPS experimental setup.

Conflicts of Interest: The authors declare no conflict of interest.

\section{References}

1. Prabhakaran, V.; Arges, C.G.; Ramani, V. In situ fluorescence spectroscopy correlates ionomer degradation to reactive oxygen species generation in an operating fuel cell. Phys. Chem. Chem. Phys. 2013, 15, 18965-18972. [CrossRef] [PubMed]

2. Zlotorowicz, A.; Jayasayee, K.; Dahl, P.I.; Thomassen, M.S.; Kjelstrup, S. Tailored porosities of the cathode layer for improved polymer electrolyte fuel cell performance. J. Power Sources 2015, 287, 472-477. [CrossRef]

3. Jayasayee, K.; Zlotorowicz, A.; Clos, D.P.; Dahl, Ø.; Thomassen, M.S.; Dahl, P.I.; Kjelstrup, S. Improved cathode catalyst layers for proton exchange membrane fuel cells. ECS Trans. 2014, 64, 321-339. [CrossRef]

4. Roen, L.M.; Paik, C.H.; Jarvi, T.D. Electrocatalytic corrosion of carbon support in PEMFC cathodes. Electrochem. Solid State Lett. 2004, 7, A19-A22. [CrossRef]

5. Schonvogel, D.; Hulstede, J.; Wagner, P.; Kruusenberg, I.; Tammeveski, K.; Dyck, A.; Agert, C.; Wark, M. Stability of Pt nanoparticles on alternative carbon supports for oxygen reduction reaction. J. Electrochem. Soc. 2017, 164, F995-F1004. [CrossRef]

6. Shao, Y.; Zhang, S.; Wang, C.; Nie, Z.; Liu, J.; Wang, Y.; Lin, Y. Highly durable graphene nanoplatelets supported Pt nanocatalysts for oxygen reduction. J. Power Sources 2010, 195, 4600-4605. [CrossRef]

7. Higgins, D.; Zamani, P.; Yu, A.; Chen, Z. The application of graphene and its composites in oxygen reduction electrocatalysis: A perspective and review of recent progress. Energy Environ. Sci. 2016, 9, 357-390. [CrossRef]

8. He, D.; Cheng, K.; Peng, T.; Sun, X.; Pan, M.; Mu, S. Bifunctional effect of reduced graphene oxides to support active metal nanoparticles for oxygen reduction reaction and stability. J. Mater. Chem. 2012, 22, 21298-21304. [CrossRef]

9. Lee, J.-S.; Jo, K.; Lee, T.; Yun, T.; Cho, J.; Kim, B.-S. Facile synthesis of hybrid graphene and carbon nanotubes as a metal-free electrocatalyst with active dual interfaces for efficient oxygen reduction reaction. J. Mater. Chem. A 2013, 1, 9603-9607. [CrossRef]

10. Chen, P.; Xiao, T.-Y.; Qian, Y.-H.; Li, S.-S.; Yu, S.-H. A nitrogen-doped graphene/carbon nanotube nanocomposite with synergistically enhanced electrochemical activity. Adv. Mater. 2013, 25, 3192-3196. [CrossRef]

11. Ratso, S.; Kruusenberg, I.; Vikkisk, M.; Joost, U.; Shulga, E.; Kink, I.; Kallio, T.; Tammeveski, K. Highly active nitrogen-doped few-layer graphene/carbon nanotube composite electrocatalyst for oxygen reduction reaction in alkaline media. Carbon 2014, 73, 361-370. [CrossRef]

12. Shui, J.; Wang, M.; Du, F.; Dai, L. N-doped carbon nanomaterials are durable catalysts for oxygen reduction reaction in acidic fuel cells. Sci. Adv. 2015, 1, e1400129. [CrossRef] [PubMed]

13. Jung, J.; Park, H.J.; Kim, J.; Hur, S.H. Highly durable Pt/graphene oxide and Pt/C hybrid catalyst for polymer electrolyte membrane fuel cell. J. Power Sources 2014, 248, 1156-1162. [CrossRef]

14. Li, Y.; Li, Y.; Zhu, E.; McLouth, T.; Chiu, C.-Y.; Huang, X.; Huang, Y. Stabilization of high-performance oxygen reduction reaction Pt electrocatalyst supported on reduced graphene oxide/carbon black composite. J. Am. Chem. Soc. 2012, 134, 12326-12329. [CrossRef] [PubMed] 
15. He, D.; Cheng, K.; Peng, T.; Pan, M.; Mu, S. Graphene/carbon nanospheres sandwich supported PEM fuel cell metal nanocatalysts with remarkably high activity and stability. J. Mater. Chem. A 2013, 1, 2126-2132. [CrossRef]

16. Pham, K.-C.; McPhail, D.S.; Mattevi, C.; Wee, A.T.S.; Chu, D.H.C. Graphene-carbon nanotube hybrids as robust catalyst supports in proton exchange membrane fuel cells. J. Electrochem. Soc. 2016, 163, F255-F263. [CrossRef]

17. Jyothirmayee Aravind, S.; Imran Jafri, R.; Rajalakshmi, N.; Ramaprabhu, S. Solar exfoliated graphene-carbon nanotube hybrid nanocomposites as efficient catalyst supports for proton exchange membrane fuel cells. J. Mater. Chem. 2011, 21, 18199-18204. [CrossRef]

18. Yoo, E.J.; Kim, J.; Hosono, E.; Zhou, H.-S.; Kudo, T.; Honma, I. Large reversible li storage of graphene nanosheet families for use in rechargeable lithium ion batteries. Nano Lett. 2008, 8, 2277-2282. [CrossRef]

19. Antolini, E. Iridium as catalyst and cocatalyst for oxygen evolution/reduction in acidic polymer electrolyte membrane electrolyzers and fuel cells. ACS Catal. 2014, 4, 1426-1440. [CrossRef]

20. Ioroi, T.; Yasuda, K. Platinum-iridium alloys as oxygen reduction electrocatalysts for polymer electrolyte fuel cells. J. Electrochem. Soc. 2005, 152, A1917-A1924. [CrossRef]

21. Holt-Hindle, P.; Yi, Q.; Wu, G.; Koczkur, K.; Chen, A. Electrocatalytic activity of nanoporous Pt-Ir materials toward methanol oxidation and oxygen reduction. J. Electrochem. Soc. 2008, 155, K5-K9. [CrossRef]

22. Zhang, G.; Shao, Z.-G.; Lu, W.; Li, G.; Liu, F.; Yi, B. One-pot synthesis of Ir@Pt nanodendrites as highly active bifunctional electrocatalysts for oxygen reduction and oxygen evolution in acidic medium. Electrochem. Commun. 2012, 22, 145-148. [CrossRef]

23. Zhang, J.; Vukmirovic, M.B.; Sasaki, K.; Nilekar, A.U.; Mavrikakis, M.; Adzic, R.R. Mixed-metal Pt monolayer electrocatalysts for enhanced oxygen reduction kinetics. J. Am. Chem. Soc. 2005, 127, 12480-12481. [CrossRef] [PubMed]

24. Lu, S.; Eid, K.; Deng, Y.; Guo, J.; Wang, L.; Wang, H.; Gu, H. One-pot synthesis of Pt-Ir tripods with a dendritic surface as an efficient catalyst for the oxygen reduction reaction. J. Mater. Chem. A 2017, 5, 9107-9112. [CrossRef]

25. Topalov, G.; Ganske, G.; Lefterova, E.; Schnakenberg, U.; Slavcheva, E. Preparation and properties of thin Pt-Ir films deposited by dc magnetron co-sputtering. Int. J. Hydrogen Energy 2011, 36, 15437-15445. [CrossRef]

26. Radev, I.; Topalov, G.; Lefterova, E.; Ganske, G.; Schnakenberg, U.; Tsotridis, G.; Slavcheva, E. Optimization of platinum/iridium ratio in thin sputtered films for PEMFC cathodes. Int. J. Hydrogen Energy 2012, 37, 7730-7735. [CrossRef]

27. Wesselmark, M.; Wickman, B.; Lagergrena, C.; Lindbergh, G. The impact of iridium on the stability of platinum on carbon thin-film model electrodes. Electrochim. Acta 2013, 111, 152-159. [CrossRef]

28. Kim, I.G.; Nah, I.W.; Oh, I.-H.; Park, S. Crumpled rGO-supported Pt-Ir bifunctional catalyst prepared by spray pyrolysis for unitized regenerative fuel cells. J. Power Sources 2017, 364, 215-225. [CrossRef]

29. Kuttiyiel, K.A.; Sasaki, K.; Choi, Y.M.; Su, D.; Liu, P.; Adzic, R.R. Bimetallic IrNi core platinum monolayer shell electrocatalysts for the oxygen reduction reaction. Energy Environ. Sci. 2012, 5, 5297-5304. [CrossRef]

30. Huang, S.-Y.; Ganesan, P.; Jung, H.-Y.; Popov, B.N. Development of supported bifunctional oxygen electrocatalysts and corrosion-resistant gas diffusion layer for unitized regenerative fuel cell applications. J. Power Sources 2012, 198, 23-29. [CrossRef]

31. Diodati, S.; Negro, E.; Vezzù, K.; Di Noto, V.; Gross, S. Oxygen reduction reaction and X-ray photoelectron spectroscopy characterisation of carbon nitride-supported bimetallic electrocatalysts. Electrochim. Acta 2016, 215, 398-409. [CrossRef]

32. Ioroi, T.; Kitazawa, N.; Yasuda, K.; Yamamoto, Y.; Takenaka, H. Iridium oxide/platinum electrocatalysts for unitized regenerative polymer electrolyte fuel cells. J. Electrochem. Soc. 2000, 147, 2018-2022. [CrossRef]

33. Yao, W.; Yang, J.; Wang, J.; Nuli, Y. Chemical deposition of platinum nanoparticles on iridium oxide for oxygen electrode of unitized regenerative fuel cell. Electrochem. Commun. 2007, 9, 1029-1034. [CrossRef]

34. da Silva, G.C.; Fernandes, M.R.; Ticianelli, E.A. Activity and stability of $\mathrm{Pt} / \mathrm{IrO}_{2}$ bifunctional materials as catalysts for the oxygen evolution/reduction reactions. ACS Catal. 2018, 8, 2081-2092. [CrossRef]

35. Takimoto, D.; Fukuda, K.; Miyasaka, S.; Ishida, T.; Ayato, Y.; Mochizuki, D.; Shimizu, W.; Sugimoto, W. Synthesis and oxygen electrocatalysis of iridium oxide nanosheets. Electrocatalysis 2017, 8, 144-150. [CrossRef]

36. Jang, S.-E.; Kim, H. Effect of water electrolysis catalysts on carbon corrosion in polymer electrolyte membrane fuel cells. J. Am. Chem. Soc. 2010, 132, 14700-14701. [CrossRef] [PubMed] 
37. Oh, J.-G.; Lee, W.H.; Kim, H. The inhibition of electrochemical carbon corrosion in polymer electrolyte membrane fuel cells using iridium nanodendrites. Int. J. Hydrogen Energy 2012, 37, 2455-2461. [CrossRef]

38. Lee, W.H.; Kim, H. Optimization of electrode structure to suppress electrochemical carbon corrosion of gas diffusion layer for unitized regenerative fuel cell. J. Electrochem. Soc. 2014, 161, F729-F733. [CrossRef]

39. Dembinska, B.; Dobrzeniecka, A.; Pisarek, M.; Kulesza, P.J. Selenourea-assisted synthesis of selenium-modified iridium catalysts: Evaluation of their activity toward reduction of oxygen. Electrochim. Acta 2015, 185, 162-171. [CrossRef]

40. Zhang, T.; Li, S.-C.; Zhu, W.; Zhang, Z.-P.; Gu, J.; Zhang, Y.-W. Shape-tunable Pt-Ir alloy nanocatalysts with high performance in oxygen electrode reactions. Nanoscale 2017, 9, 1154-1165. [CrossRef]

41. Jovanovič, P.; Hodnik, N.; Ruiz-Zepeda, F.; Arčon, I.; Jozinović, B.; Zorko, M.; Bele, M.; Šala, M.; Šelih, V.S.; Hočevar, S.; et al. Electrochemical dissolution of iridium and iridium oxide particles in acidic media: Transmission electron microscopy, electrochemical flow cell coupled to inductively coupled plasma mass spectrometry, and X-ray absorption spectroscopy study. J. Am. Chem. Soc. 2017, 139, 12837-12846. [CrossRef]

42. Choi, H.C.; Shim, M.; Bangsaruntip, S.; Dai, H. Spontaneous reduction of metal ions on the sidewalls of carbon nanotubes. J. Am. Chem. Soc. 2002, 124, 9058-9059. [CrossRef] [PubMed]

43. Chen, X.; Wu, G.; Chen, J.; Chen, X.; Xie, Z.; Wang, X. Synthesis of "clean" and well-dispersive Pd nanoparticles with excellent electrocatalytic property on graphene oxide. J. Am. Chem. Soc. 2011, 133, 3693-3695. [CrossRef] [PubMed]

44. Yin, H.; Tang, H.; Wang, D.; Gao, Y.; Tang, Z. Facile synthesis of surfactant-free au cluster/graphene hybrids for high-performance oxygen reduction reaction. ACS Nano 2012, 6, 8288-8297. [CrossRef] [PubMed]

45. Wang, C.; Ciganda, R.; Yate, L.; Tuninetti, J.; Shalabaeva, V.; Salmon, L.; Moya, S.; Ruiz, J.; Astruc, D. Redox synthesis and high catalytic efficiency of transition-metal nanoparticle-graphene oxide nanocomposites. J. Mater. Chem. A 2017, 5, 21947-21954. [CrossRef]

46. Stobinski, L.; Lesiak, B.; Malolepszy, A.; Mazurkiewicz, M.; Mierzwa, B.; Zemek, J.; Jiricek, P.; Bieloshapka, I. Graphene oxide and reduced graphene oxide studied by the XRD, TEM and electron spectroscopy methods. J. Electron. Spectrosc. Relat. Phenom. 2014, 195, 145-154. [CrossRef]

47. Langford, J.I.; Wilson, A.J.C. Scherrer after sixty years: A survey and some new results in the determination of crystallite size. J. Appl. Cryst. 1978, 11, 102-113. [CrossRef]

48. Lesiak, B.; Mazurkiewicz, M.; Malolepszy, A.; Stobinski, L.; Mierzwa, B.; Mikolajczuk-Zychora, A.; Juchniewicz, K.; Borodzinski, A.; Zemec, J.; Jiricek, P. Effect of the Pd/MWCNTs anode catalysts preparation methods on their morphology and activity in a direct formic acid fuel cell. Appl. Surf. Sci. 2016, 387, $929-937$. [CrossRef]

49. Platinum Transition Metal. Available online: https://xpssimplified.com/elements/platinum.php (accessed on 10 February 2020).

50. van Spronsen, M.A.; Frenken, J.W.M.; Groot, I.M.N. Observing the oxidation of platinum. Nat. Commun. 2017, 8, 42. [CrossRef]

51. El Sawy, E.N.; Birss, V.I. Nano-porous iridium and iridium oxide thin films formed by high efficiency electrodeposition. J. Mater. Chem. 2009, 19, 8244-8252. [CrossRef]

52. Chastain, J.; King, R.C., Jr. Handbook of X-ray Photoelectron Spectroscopy; Physical Electronics Inc.: Eden Prairie, MN, USA, 1995.

53. Birss, V.I.; Andreas, H.; Serebrennikova, I.; Elzanowska, H. Electrochemical characterization of sol-gel formed Ir metal nanoparticles. Electrochem. Solid State Lett. 1999, 2, 326-329. [CrossRef]

54. Lee, K.; Zhang, L.; Zhang, J. A novel methanol-tolerant Ir-Se chalcogenide electrocatalyst for oxygen reduction. J. Power Sources 2007, 165, 108-113. [CrossRef]

55. Liu, G.; Zhang, H. Facile synthesis of carbon-supported IrxSey chalcogenide nanoparticles and their electrocatalytic activity for the oxygen reduction reaction. J. Phys. Chem. C 2008, 112, 2058-2065. [CrossRef]

56. Neergat, M.; Gunasekar, V.; Singh, R.K. Oxygen reduction reaction and peroxide generation on Ir, Rh, and their selenides-A comparison with Pt and RuSe. J. Electrochem. Soc. 2011, 158, B1060-B1066. [CrossRef]

57. Masa, J.; Batchelor-McAuley, C.; Schuhmann, W.; Compton, R.G. Koutecky-Levich analysis applied to nanoparticle modified rotating disk electrodes: Electrocatalysis or misinterpretation? Nano Res. 2014, 7, 71-78. [CrossRef] 
58. Chatenet, M.; Genies-Bultel, L.; Aurousseau, M.; Durand, R.; Andolfatto, F. Oxygen reduction on silver catalysts in solutions containing various concentrations of sodium hydroxide-Comparison with platinum. J. Appl. Electrochem. 2009, 32, 1131-1140. [CrossRef]

59. Antoine, O.; Durand, R. RRDE Study of oxygen reduction on Pt nanoparticles inside $\mathrm{Nafion}^{\circledR}: \mathrm{H}_{2} \mathrm{O}_{2}$ production in PEMFC cathode conditions. J. Appl. Electrochem. 2009, 30, 839-844. [CrossRef]

60. Schmidt, T.J.; Paulus, U.A.; Gasteiger, H.A.; Behm, R.J. The oxygen reduction reaction on a Pt/carbon fuel cell catalyst in the presence of chloride anions. J. Electroanal. Chem. 2001, 508, 41-47. [CrossRef]

61. Hoare, J.P. Oxygen overvoltage on bright iridium. J. Electroanal. Chem. 1968, 18, 251-259. [CrossRef]

62. Cherevko, S.; Geiger, S.; Kasian, O.; Mingers, A.; Mayrhofer, K.J.J. Oxygen evolution activity and stability of iridium in acidic media. Part 1.-Metallic iridium. J. Electroanal. Chem. 2016, 773, 69-78. [CrossRef]

63. Schneider, C.A.; Rasband, W.S.; Eliceiri, K.W. NIH Image to ImageJ: 25 years of image analysis. Nat. Methods 2012, 9, 671-675. [CrossRef] [PubMed]

64. Lindau, I.; Pianetta, P.; Yu, K.Y.; Spicer, W.E. Photoemission of gold in the energy range 30-300 eV using synchrotron radiation. Phys. Rev. B 1976, 13, 492-495. [CrossRef]

65. CasaXPS. Processing Software for XPS, AES, SIMS and More. Available online: http://www.casaxps.com (accessed on 10 February 2020).

66. Kulesza, P.J.; Zak, J.K.; Rutkowska, I.A.; Dembinska, B.; Zoladek, S.; Miecznikowski, K.; Negro, E.; Di Noto, V.; Zelanay, P. Elucidation of role of graphene in catalytic designs for electroreduction of oxygen. Curr. Opin. Electrochem. 2018, 9, 257-264. [CrossRef]

(C) 2020 by the authors. Licensee MDPI, Basel, Switzerland. This article is an open access article distributed under the terms and conditions of the Creative Commons Attribution (CC BY) license (http://creativecommons.org/licenses/by/4.0/). 